\section{Response to: 'The reference levels of serum urate for clinically evident incident gout' by Chen and Ding}

We thank Drs Chen and Ding ${ }^{1}$ for their interest in our recent paper describing the relationship between serum urate concentrations and risk of developing incident gout. ${ }^{2}$ They suggest that we calculate benchmark dose estimates for serum urate and gout risk. Benchmark dose estimates are used in the field of occupational epidemiology to evaluate the minimal levels of exposure to an environmental toxin needed to cause a prespecified increase in an adverse event.

We are not aware of this approach being applied to clinical parameters that are not external exposures and are uncertain about validity of such an approach for serum urate, noting that all humans have some 'exposure' to urate, which is a circulating biochemical analyte. Estimation of the benchmark dose also requires a predetermined increase in risk (eg, 10\% extra risk or change in the mean equal to one SD). At present, the clinically meaningful increase in gout risk is unknown. For these reasons, we have not provided benchmark dose estimates.

Nicola Dalbeth, ${ }^{1}$ Amanda Phipps-Green, ${ }^{2}$ Christopher Frampton, ${ }^{3}$ Tuhina Neogi, ${ }^{4}$ William J Taylor, ${ }^{5}$ Tony R Merriman ${ }^{2}$

${ }^{1}$ Department of Medicine, University of Auckland, Auckland, New Zealand ${ }^{2}$ Department of Biochemistry, University of Otago, Dunedin, New Zealand ${ }^{3}$ Department of Medicine, University of Otago, Christchurch, New Zealand ${ }^{4} \mathrm{Clinical}$ Epidemiology Research and Training Unit, Boston University School of Medicine, Boston, Massachusetts, USA

${ }^{5}$ Department of Medicine, University of Otago, Wellington, New Zealand
Correspondence to Prof Nicola Dalbeth, Department of Medicine, Faculty of Medical and Health Sciences, University of Auckland, Grafton, Auckland 1023, New Zealand; n.dalbeth@auckland.ac.nz

Handling editor Josef S Smolen

Funding The authors have not declared a specific grant for this research from any funding agency in the public, commercial or not-for-profit sectors.

Competing interests None declared.

Provenance and peer review Commissioned; internally peer reviewed.

(c) Article author(s) (or their employer(s) unless otherwise stated in the text of the article) 2019. All rights reserved. No commercial use is permitted unless otherwise expressly granted.

\section{Check for updates}

To cite Dalbeth N, Phipps-Green A, Frampton C, et al. Ann Rheum Dis 2019;78:e42.

Received 14 March 2018

Accepted 14 March 2018

Published Online First 21 March 2018

\section{Linked}

- http://dx.doi.org/10.1136/annrheumdis-2018-213355

Ann Rheum Dis 2019;78:e42. doi:10.1136/annrheumdis-2018-213372

\section{REFERENCES}

1 Chen X, Ding X. The reference levels of serum urate for clinically evident incident gout. Ann Rheum Dis 2018. eLetter.

2 Dalbeth N, Phipps-Green A, Frampton C, et al. Relationship between serum urate concentration and clinically evident incident gout: an individual participant data analysis. Ann Rheum Dis 2018;77:1048-52. 